\title{
Rapid identification and quantification of Campylobacter coli and Campylobacter jejuni by real-time PCR in pure cultures and in complex samples
}

Mily Leblanc-Maridor ${ }^{1,2^{*}}$, François Beaudeau ${ }^{1,2}$, Henri Seegers ${ }^{1,2}$, Martine Denis ${ }^{3}$ and Catherine Belloc ${ }^{1,2}$

\begin{abstract}
Background: Campylobacter spp., especially Campylobacter jejuni (C. jejuni) and Campylobacter coli (C. coli), are recognized as the leading human foodborne pathogens in developed countries. Livestock animals carrying Campylobacter pose an important risk for human contamination. Pigs are known to be frequently colonized with Campylobacter, especially C. coli, and to excrete high numbers of this pathogen in their faeces. Molecular tools, notably real-time PCR, provide an effective, rapid, and sensitive alternative to culture-based methods for the detection of C. coli and C. jejuni in various substrates. In order to serve as a diagnostic tool supporting Campylobacter epidemiology, we developed a quantitative real-time PCR method for species-specific detection and quantification of C. coli and C. jejuni directly in faecal, feed, and environmental samples.

Results: With a sensitivity of 10 genome copies and a linear range of seven to eight orders of magnitude, the $C$. coli and C. jejuni real-time PCR assays allowed a precise quantification of purified DNA from C. coli and C. jejuni. The assays were highly specific and showed a 6-log-linear dynamic range of quantification with a quantitative detection limit of approximately $2.5 \times 10^{2} \mathrm{CFU} / \mathrm{g}$ of faeces, $1.3 \times 10^{2} \mathrm{CFU} / \mathrm{g}$ of feed, and $1.0 \times 10^{3} \mathrm{CFU} / \mathrm{m}^{2}$ for the environmental samples. Compared to the results obtained by culture, both C. coli and C. jejuni real-time PCR assays exhibited a specificity of $96.2 \%$ with a kappa of 0.94 and 0.89 respectively. For faecal samples of experimentally infected pigs, the coefficients of correlation between the C. coli or C. jejuni real-time PCR assay and culture enumeration were $R^{2}=0.90$ and $R^{2}=0.93$ respectively.

Conclusion: The C. coli and C. jejuni real-time quantitative PCR assays developed in this study provide a method capable of directly detecting and quantifying C. coli and C. jejuni in faeces, feed, and environmental samples. These assays represent a new diagnostic tool for studying the epidemiology of Campylobacter by, for instance,

investigating the carriage and excretion of C. coli and C. jejuni by pigs from conventional herds.
\end{abstract}

\section{Background}

Campylobacter spp. are recognized as the leading human foodborne pathogens in developed countries $[1,2]$. Within the genus Campylobacter, the thermophilic species Campylobacter jejuni (C. jejuni) and Campylobacter coli (C. coli) are the most frequently associated with illness, accounting for over $95 \%$ of infections (respectively responsible for 80 to $85 \%$ and 10 to $15 \%$ )

\footnotetext{
* Correspondence: leblanc.maridor@gmail.com

'LUNAM Université, Oniris, UMR 1300 Biologie, épidémiologie et analyse des risques, Nantes, F-44307, France

Full list of author information is available at the end of the article
}

[2]. These two species commonly live in the intestinal tract of birds and mammals, including food production animals and pets, without causing clinical signs [3]. Livestock animals carrying Campylobacter pose an important risk for human infection from contamination of carcasses at slaughter, of milk, and water contaminated by livestock wastes and slurries [4-6]. Research carried out in Europe has shown the dominance of $C$. jejuni in animal intestinal tracts, for example, broiler chickens, cattle, and wild-living mammals and birds $[2,7,8]$. Pigs are known to be frequently infected with Campylobacter (prevalence between 50\% and 100\%), to

\section{(Ciomed Central}


exhibit high counts of this pathogen in their faeces (ranging from $10^{2}$ to $10^{7}$ Colony Forming Units (CFU) of Campylobacter per gram), and to show a dominance of C. coli [9-11]. Nevertheless, some studies have found a dominance of $C$. jejuni in pigs and of $C$. coli in chickens [12-15]. Given these contradictory data, the risk of foodborne disease associated with animal species is not clear. In terms of risk assessment, the ability to differentiate and quantify these two species is essential to describe more precisely the presence of Campylobacter in livestock animals.

The identification of Campylobacter using conventional methods is slow (culture-based methods can take up to five days) and problematic due to their fastidious growth requirements and biochemical inertness [16,17]. Moreover, the detection of C. coli and/or C. jejuni in complex substrates like faeces or environmental samples is difficult as the culture conditions have to be selective enough to avoid overgrowth from competiting organisms. Additionally these bacteria may enter into a viable but nonculturable state (VBNC) [18]. The correct differentiation of thermophilic Campylobacter spp., especially C. coli and C. jejuni, by phenotypic tests is difficult and hippurate hydrolysis test used to distinguish these two species is often problematic [19]. Furthermore, C. jejuni may also coexist with $C$. coli in pigs, but at 10-100-fold lower numbers than $C$. coli $[10,11,20]$, so $C$. jejuni will be less frequently isolated from such samples because only a few colonies are identified to the species level with conventional culturing and biochemical testing techniques. Molecular methods are an alternative to the bacteriological method for the detection of $C$. coli and C. jejuni in various substrates $[1,17,21-24]$. Real-time PCR has provided a reliable tool to detect and to quantify C. jejuni and/or C. coli in pure culture [25], in poultry, milk, or water $[26,27]$, and in complex substrates like food products [28-30] and faecal samples [20,31-33]. However, of the real-time PCR techniques developed, none were capable of differentiating and quantifying $C$. coli and C. jejuni directly from pig faecal, feed, and environmental samples.

The present study aimed to develop a species-specific real-time PCR method to detect and quantify C. coli and $C$. jejuni directly in pig faecal, feed, and environmental samples. The first step in the development of the assay was the definition of the multiplex PCR assay to quantify C. coli and C. jejuni isolates from bacterial cultures. These real-time PCR assays were coupled with a modified DNA extraction protocol and then examined for their ability: (i) to evaluate DNA purification with different parameters (potential presence of PCR inhibitory compounds, DNA yield, and reproducibility), (ii) to measure the sensitivity and the specificity of PCR-based detection in faecal samples, and (iii) to detect $C$. jejuni among predominant $C$. coli. Finally, the last step was the application of the real-time PCR assays to detect and quantify C. coli and C. jejuni in complex substrates like feed, environmental samples, and faeces from experimentally as well as naturally infected pigs. The bacterial culture was used as a gold standard for their validation.

\section{Results}

\section{Specificity, sensitivity and linear range of the real-time PCR assays}

The specificity of each primers-probe set for the detection of $C$. coli and C. jejuni was tested against different strains of C. coli $(\mathrm{n}=77)$ and $C$. jejuni $(\mathrm{n}=54)$, all of which were correctly identified. Moreover, no signal was observed for any of the other Campylobacter species tested as well as for a range of bacteria, which could be present in faecal samples or responsible for diarrhoea in pigs and humans (Table 1). Finally, the specificity of each real-time PCR assay was characterized for samples using the stool-screening strategy described previously by Lagier et al. (2004) [33]. The DNA extracted from the 30 Campylobacter-negative faecal, feed, and environmental samples and examined in duplicate with each real-time PCR assays produced threshold cycle $(\mathrm{Ct})$ values $\geq 42$ when $5 \mu \mathrm{L}$ of extracted DNA was used as the starting template. All samples in which both duplicates had a $\mathrm{Ct}$ value below this threshold were regarded as positive.

To determine the linear range of the real-time PCR assay, standard curves of the template DNA, in units of genome copy number, were generated for $C$. coli (Figure 1a) and for C. jejuni (Figure 1b). We observed a strong linear correlation ( $R^{2}$ values were all equal to 0.99$)$, providing an accurate measurement over a large variety of starting target amounts (Figure 1). The detection limits of the real-time PCR assays for genomic DNA were three genome copies per PCR reaction for C. coli and ten genome copies per PCR reaction for C. jejuni (Figure 1). Moreover, the reaction is reliable with a detection limit of ten genome copies for the samples containing both C. jejuni and C. coli DNA (Figure 2) and for 10 successive real-time PCR assays. The standard curves showed linearity over the entire quantitation range and spanned eight and seven orders of magnitude for C. coli and C. jejuni detection, respectively. Finally, the real-time PCR assays had an efficiency of $99 \%$ to detect C. jejuni and C. coli whether alone (Figure 1) or together in a same sample (Figure 2).

\section{Precision of the $C$. jejuni and $C$. coli real-time PCR assays}

To obtain values for the intra- and inter-assay variation of each real-time PCR assay, purified genomic DNA from $10^{1}$ to $10^{8}$ genome copies per PCR reaction was subjected 
Table 1 List of strains used for the validation of specificity of Campylobacter coli and Campylobacter jejuni real-time PCR assays

\begin{tabular}{|c|c|c|c|}
\hline Bacterial species $(n)$ & Name or origin of strain & $\begin{array}{l}\text { C. coli real-time PCR } \\
\text { identification }\end{array}$ & $\begin{array}{l}\text { C. jejuni real-time PCR } \\
\text { identification }\end{array}$ \\
\hline Campylobacter coli (2) & CCUG 11283, CIP 7081 & Positive & Negative \\
\hline C. coli pig isolates (25) & Anses, ENVN-INRA & Positive & Negative \\
\hline C. coli poultry isolates (25) & Anses, ENVN-INRA & Positive & Negative \\
\hline C. coli human isolates (25) & Anses, CNR-CH & Positive & Negative \\
\hline $\begin{array}{l}\text { Campylobacter jejuni subsp jejuni } \\
\text { (3) }\end{array}$ & $\begin{array}{l}\text { CCUG 11284, NCTC 11168, NCTC } \\
81176\end{array}$ & Negative & Positive \\
\hline C. jejuni & CIP 103726 & Negative & Positive \\
\hline C. jejuni poultry isolates (25) & Anses, ENVN-INRA & Negative & Positive \\
\hline C. jejuni human isolates (25) & Anses, ENVN-INRA, CNR-CH & Negative & Positive \\
\hline $\begin{array}{l}\text { Campylobacter fetus subsp fetus } \\
\text { (2) }\end{array}$ & CCUG 68231, CIP 2595396 & Negative & Negative \\
\hline $\begin{array}{l}\text { Campylobacter fetus subsp } \\
\text { venerealis }\end{array}$ & CCUG 33899 & Negative & Negative \\
\hline Campylobacter hyointestinalis & CCUG 14169 & Negative & Negative \\
\hline Campylobacter lari (3) & $\begin{array}{l}\text { CCUG 23947, ATCC 35222, CIP } \\
107080\end{array}$ & Negative & Negative \\
\hline Campylobacter upsaliensis (2) & CCUG 14913, CIP 400 & Negative & Negative \\
\hline Campylobacter sputorum & CIP 103749 & Negative & Negative \\
\hline Helicobacter canis & CIP 104753 & Negative & Negative \\
\hline Helicobacter felis & CIP 104382 & Negative & Negative \\
\hline Helicobacter mustelae & CIP 103759 & Negative & Negative \\
\hline Helicobacter pullorum & CIP 104787 & Negative & Negative \\
\hline Helicobacter pylori (3) & CIP 103995, CIP 26695, CIP 101260 & Negative & Negative \\
\hline Wolinella succinogenes & CCUG 13145 & Negative & Negative \\
\hline Arcobacter butzleri & CCUG 30485 & Negative & Negative \\
\hline Arcobacter cryaerophilus & CIP 104014 & Negative & Negative \\
\hline Listeria monocytogenes (3) & $\begin{array}{l}\text { CIP 103575, ATCC 895807, ATCC } \\
19115\end{array}$ & Negative & Negative \\
\hline Listeria innocua (3) & CCUG 15531, ENVN-INRA & Negative & Negative \\
\hline $\begin{array}{l}\text { Salmonella enterica serovar } \\
\text { enteridis }\end{array}$ & ENVN-INRA & Negative & Negative \\
\hline S. enterica serovar typhimurium & ATCC 13311 & Negative & Negative \\
\hline Enterococcus faecalis (2) & CIP 103013, CCUG 19916 & Negative & Negative \\
\hline Escherichia coli & V517 & Negative & Negative \\
\hline Pseudomonas aeruginosa (2) & ENVN-INRA & Negative & Negative \\
\hline Enterobacter aerogenes (2) & ENVN-INRA & Negative & Negative \\
\hline Staphylococcus aureus (2) & ENVN-INRA & Negative & Negative \\
\hline Yersinia ruckeri & ATCC 29473 & Negative & Negative \\
\hline Y. ruckeri fish isolates (5) & ENVN-INRA & Negative & Negative \\
\hline
\end{tabular}

$n$, number of strains

NCTC, National Collection of Type Cultures (Colindale, UK); CCUG, Culture Collection University of Göteborg (Göteborg, Sweden); ATCC, American Type Culture Collection (Manassas, Va); CIP, Collection of the Pasteur Institute (Paris, France); Anses: Strains from the collection of the French Agency for Food Safety (Ploufragan, France); CNR-CH: Strains isolated from the collection of the French National Reference Center for Campylobacter and Helicobacter (Bordeaux, France); ENVN-INRA: Strains isolated from our in-house collection

to each real-time PCR in ten duplicates, with 10 different mixes performed on different runs. The results are presented in Table 2. The coefficients of variation (CV) of the $\mathrm{Ct}$ values for the ten different intra-assay experiments ranged from 0.81 to $2.27 \%$ for C. coli real-time PCR and from 0.35 to $5.63 \%$ for $C$. jejuni real-time PCR. The mean standard curves were $y=-3.33 x+40.17$ with $R^{2}=0.99$ for $C$. coli PCR and $y=-3.33 x+40.53$ with $\mathrm{R}^{2}=0.99$ for $C$. jejuni PCR. The CV of the Ct values for the inter-assay variation ranged from 1.52 to $4.89 \%$ and from 0.67 to $2.65 \%$, respectively for $C$. coli and C. jejuni real-time PCR assays. The mean standard curves were $y=-3.39 x+42.70$ for the C. coli real-time PCR and $y=-3.20 x+40.20$ for the $C$. jejuni real-time PCR. 


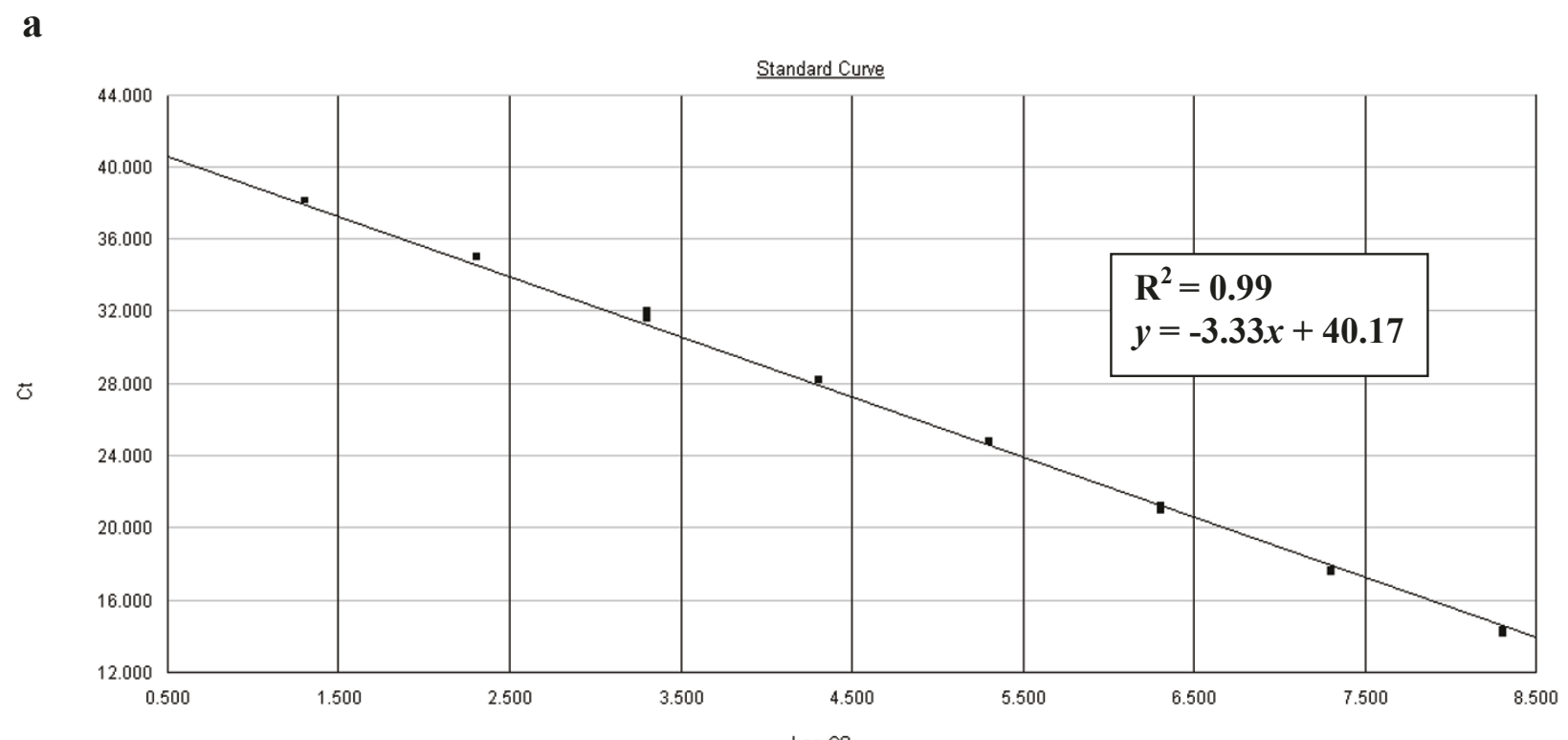

b

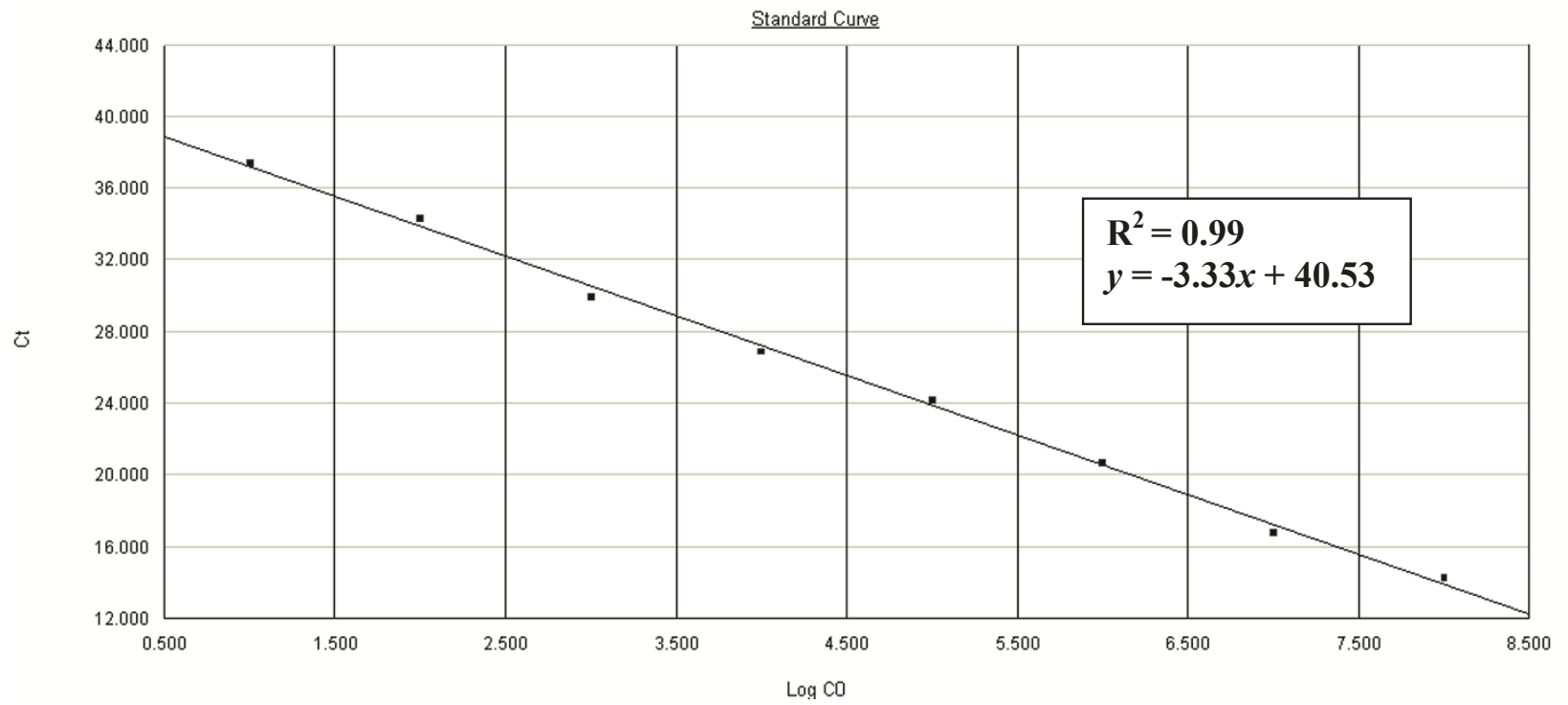

Figure 1 Dynamic range and sensitivity of the Campylobacter coli and Campylobacter jejuni real-time PCR assays. Standard curves of 10fold serial dilution of standard DNA of (a) C. coli CIP 70.81 (from $0.3 \times 10^{1}$ to $3.0 \times 10^{8}$ genome copies per PCR reaction) and of (b) C. jejuni NCTC 11168 (from $10^{1}$ to $10^{8}$ genome copies per PCR reaction) are reported, each dot representing the result of duplicate amplification of each dilution. The coefficients of determination $R^{2}$ and the slopes of each regression curve are indicated. The standard curves are obtained by correlation of the threshold cycle values (Ct) and $\log _{10}$ input genome copy number (Log CO) from the amplification plot.

Validation of the real time PCR assays for the analysis of faecal, feed, and environmental samples spiked with $C$. coli and C. jejuni

Samples were checked for PCR inhibition in a separate test using a bacterial internal amplification and extraction control [34]. Inhibitors of real-time PCR were identified in $4 \%$ of the examined samples, which were consequently removed from the quantification study.
The detection limit for the quantitative real-time PCR assays in spiked faecal samples were $2.5 \times 10^{2} \mathrm{CFU}$ of C. coli/g of faeces and $2.0 \times 10^{2} \mathrm{CFU}$ of C. jejuni/g of faeces (Figure 3), similar to that of the bacteriological method. Although this assay was able to detect lower quantities between $5.0 \times 10^{1}$ and $2.0 \times 10^{2} \mathrm{CFU}$ of Campylobacter/g of faeces, the regression curve was only linear from about $10^{2}$ to $10^{7} \mathrm{CFU}$ with reaction volumes of $20 \mu \mathrm{L}$ (Figure 3). For the feed samples, the 
a

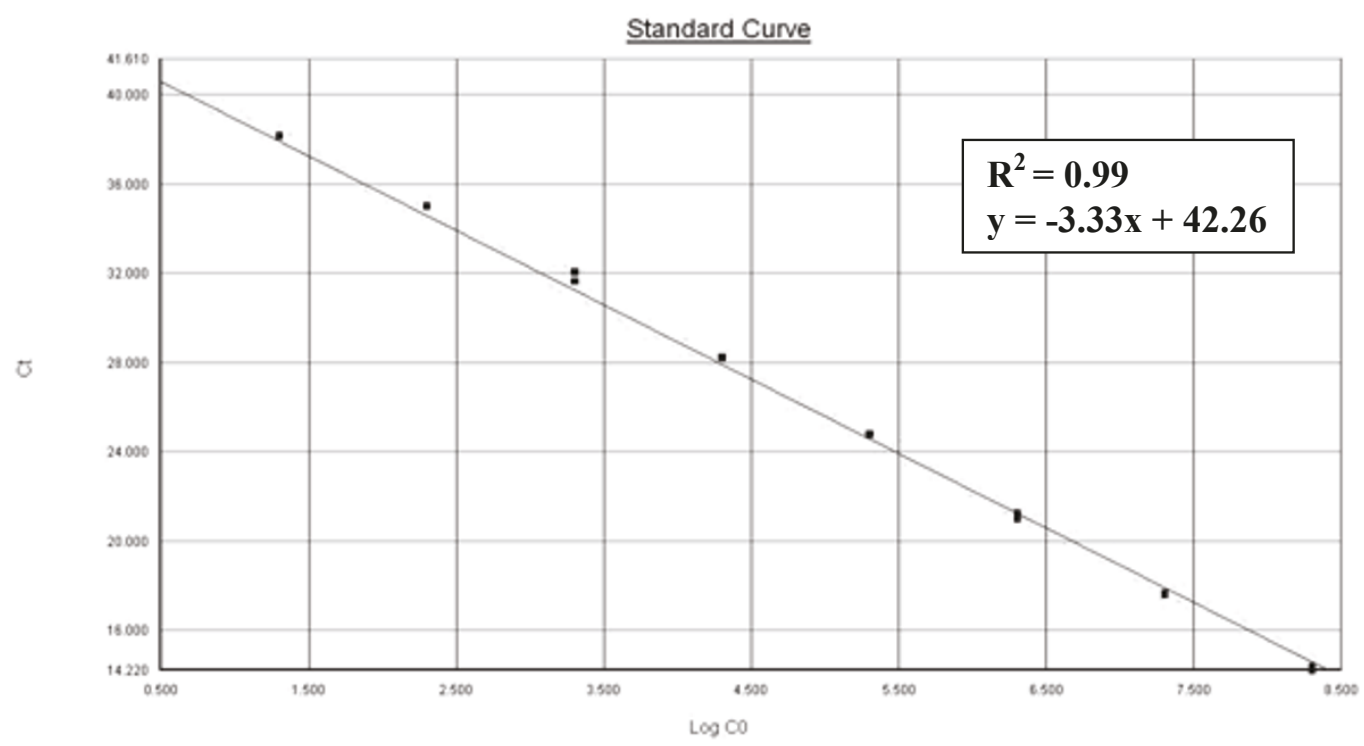

b

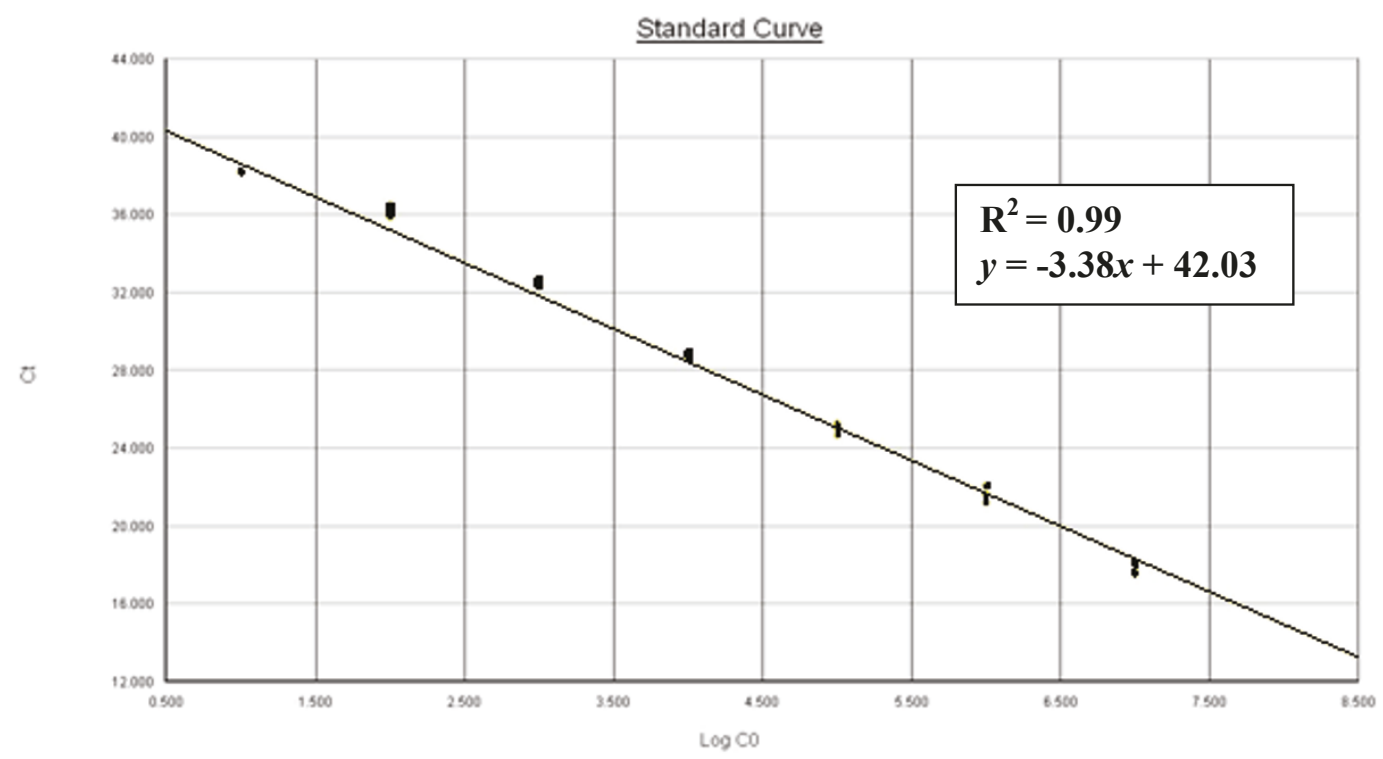

Figure 2 Dynamic range and sensitivity of the Campylobacter coli and Campylobacter jejuni real-time PCR assays with samples containing roughly equal genome copies of both species. The linear range of each real-time PCR assay was determined using C. coli CIP 70.81 and C. jejuni NCTC 11168 standard DNA together. Standard curves of 10-fold serial dilution of both C. coli and C. jejuni standard DNA (roughly from $10^{1}$ to $10^{8}$ genome copies of each species per PCR reaction) by (a) C. coli real-time PCR assay and by (b) C. jejuni real-time PCR assay are reported, each dot representing the result of duplicate amplification of each dilution. The coefficients of determination and the slopes of each regression curve are indicated. The standard curves are obtained by correlation of the threshold cycle values $(\mathrm{Ct})$ and $\log _{10}$ input genome copy number (Log CO) from the amplification plot.

detection limits were slightly lower $\left(1.1 \times 10^{2} \mathrm{CFU}\right.$ of $C$. coli/g of feed and $1.3 \times 10^{2}$ CFU of C. jejuni/g of feed). For the environmental samples, they were around $10^{3}$ $\mathrm{CFU} / \mathrm{m}^{2}$ for both species and both sampling sites (pen walls and floor swabs). For both species, the standard curves showed linearity from about $10^{2}$ to $10^{8} \mathrm{CFU}$ and
$10^{3}$ to $10^{7} \mathrm{CFU}$ for feed and environmental samples respectively.

To obtain values for the intra- and inter-assay variation of each real-time PCR assay with field samples, DNA extracted from the Campylobacter-negative spiked faecal samples was subjected to each real-time PCR in 
Table 2 Intra- and Inter-assay variabilities of $C$. coli and C. jejuni real-time PCR assays for the standard curves generated with purified genomic DNA of C. coli CIP 70.81 and C. jejuni NCTC 11168, ranging from $10^{1}$ to $10^{8}$ genome copies per PCR reaction (genome copy number) and with DNA extracted from Campylobacter-negative pig faecal samples spiked with different amounts of $C$. coli and C. jejuni ranging from $2 \times 10^{2}$ to $2 \times 10^{7} \mathrm{CFU} / \mathrm{g}$ of faeces including the DNA extraction procedure (CFU/g of faeces)

\begin{tabular}{|c|c|c|c|c|c|c|c|c|}
\hline \multirow[b]{3}{*}{ Genome copy number } & \multicolumn{4}{|c|}{ Intra-assay ${ }^{1}$} & \multicolumn{4}{|c|}{ Inter-assay $^{2}$} \\
\hline & \multicolumn{2}{|c|}{ C. coli } & \multicolumn{2}{|c|}{ C. jejuni } & \multicolumn{2}{|c|}{ C. coli } & \multicolumn{2}{|c|}{ C. jejuni } \\
\hline & $\mathrm{CV}_{\mathrm{c}}(\%)$ & Ct range & $C V_{j}(\%)$ & Ct range & $\mathrm{CV}_{\mathrm{c}}(\%)$ & Ct range & $C V_{j}(\%)$ & Ct range \\
\hline $10^{8}$ & 2.27 & $14.18-15.25$ & 5.63 & $14.18-17.15$ & 4.89 & $13.86-16.11$ & 1.94 & $14.30-15.01$ \\
\hline $10^{7}$ & 1.33 & $16.63-17.71$ & 0.95 & $17.55-18.21$ & 4.69 & $16.33-17.88$ & 0.83 & $17.86-18.27$ \\
\hline $10^{6}$ & 1.99 & $20.05-20.78$ & 1.13 & $21.02-21.81$ & 3.42 & $19.29-21.80$ & 1.37 & $21.15-22.04$ \\
\hline $10^{5}$ & 1.60 & $23.32-24.63$ & 0.57 & $24.15-24.69$ & 4.08 & $23.22-25.55$ & 0.67 & $24.01-24.48$ \\
\hline $10^{4}$ & 0.81 & $26.92-28.07$ & 0.35 & $26.56-26.91$ & 1.52 & $26.23-28.48$ & 2.65 & $26.64-28.30$ \\
\hline $10^{3}$ & 1.28 & $30.44-31.28$ & 0.53 & $30.11-30.69$ & 1.90 & $29.70-31.37$ & 1.99 & $28.60-30.85$ \\
\hline $10^{2}$ & 1.22 & $33-37-34.82$ & 0.40 & $33.66-34.05$ & 2.46 & $33.80-35.78$ & 1.39 & $33.62-34.60$ \\
\hline $10^{1}$ & 0.87 & $37.29-38.66$ & 2.21 & $35.65-37.77$ & 3.10 & $37.10-38.91$ & 2.21 & $36.11-37.43$ \\
\hline CFU/g of faeces & $\mathrm{CV}_{\mathrm{c}}(\%)$ & Ct range & $\mathrm{CV}_{\mathrm{j}}(\%)$ & Ct range & $\mathrm{CV}_{\mathrm{c}}(\%)$ & Ct range & $C V_{j}(\%)$ & Ct range \\
\hline $2 \times 10^{8}$ & 3.23 & $17.22-18.35$ & 2.28 & $18-74-19.81$ & - & - & - & - \\
\hline $2 \times 10^{7}$ & 1.33 & $20.60-21.15$ & 2.53 & $20.57-22.02$ & 0.75 & $19.54-19.88$ & 1.21 & $21.65-22.27$ \\
\hline $2 \times 10^{6}$ & 1.89 & $24.08-24.97$ & 0.91 & $24.13-24.62$ & 2.37 & $23.51-24.85$ & 0.70 & $24.15-24.60$ \\
\hline $2 \times 10^{5}$ & 1.15 & $27.23-28.38$ & 1.40 & $27.02-28.45$ & 0.57 & $26.40-26.79$ & 1.46 & $27.04-28.69$ \\
\hline $2 \times 10^{4}$ & 2.20 & $28.28-29.75$ & 1.98 & $30.13-31.80$ & 2.58 & $28.00-29.90$ & 2.10 & $30.7-32.31$ \\
\hline $2 \times 10^{3}$ & 4.40 & $32.20-33.77$ & 1.62 & $34.61-35.96$ & 2.07 & $32.00-33.22$ & 1.80 & $34.48-36.45$ \\
\hline $2 \times 10^{2}$ & 4.38 & $34.61-37.78$ & 1.76 & 38.04-39.37 & 1.64 & $35.35-36.56$ & 1.92 & $37.34-39.03$ \\
\hline
\end{tabular}

The coefficients of variation $(C V)$ of the threshold cycles values $(C t)$ were evaluated for the $C$. coli real-time $P C R\left(C V_{c}\right)$ and for the $C$. jejuni real-time $P C R\left(C V_{j}\right)$. For each $\mathrm{CV}_{\mathrm{c}}$ and $\mathrm{CV}_{\mathrm{j}}$, the range of $\mathrm{Ct}(\mathrm{Ct}$ range), which corresponds to the smallest and the highest values of the $\mathrm{Ct}$ found among the ten, was indicated for each dilution for both intra-and inter-assay testings.

1 Results of intra-assay testing: ten replicates of each sample were tested in one PCR run

${ }^{2}$ Results of inter-assay testing: one replicate of each sample was tested once in each of ten different PCR runs

ten duplicates, with 10 different mixes performed on different runs. The results are reported in Table 2. The CV of the $\mathrm{Ct}$ values for the ten different intra-assay experiments ranged from 1.15 to $4.40 \%$ for $C$. coli real-time PCR and from 0.91 to $2.53 \%$ for C. jejuni real-time PCR. The standard curves were $y=-3.33 x+45.82$ with $R^{2}=$ 0.98 for C. coli and $y=-3.24 x+46.00$ with $\mathbf{R}^{2}=0.98$ for $C$. jejuni. The CV of the Ct values for the ten different inter-assay experiments, including the DNA extraction procedure, ranged from 0.57 to $2.58 \%$ and from 0.70 to $2.10 \%$ respectively for $C$. coli and $C$. jejuni realtime PCR assays. The mean standard curves were $y=$ $-3.36 x+43.70$ and $y=-3.25 x+46.20$ respectively.

Analysis of faecal samples of experimentally infected pigs The numbers of positive and negative samples for experimentally infected pigs determined by either realtime PCR or bacteriological method are summarized in Table 3. There was an excellent correlation at the qualitative level with both techniques with a kappa of 0.94 and 0.89 respectively for $C$. coli and $C$. jejuni real-time PCR assays. Indeed, for $C$. jejuni experimentally infected pigs, only two culture-positive samples were negative by real-time PCR, and one culture-negative sample was positive by real-time PCR (specificity of $96.2 \%)$. In addition, for pigs experimentally infected with $C$. coli, only one culture-negative sample was positive by real-time PCR and inversely (specificity of $96.2 \%$ ).

The estimate of Campylobacter CFU/g of faeces by both $C$. coli and C. jejuni real-time PCR assays was compared to the bacteriological enumeration method (Figure 4). We observed a good correlation between real-time PCR and culture at the quantitative level for experimentally infected pig samples both for C. coli real-time PCR $\left(\mathrm{R}^{2}=0.94\right)$ and for $C$. jejuni real-time PCR $\left(\mathrm{R}^{2}=0.86\right)$. Among the PCR-culture positive samples for the experimentally infected pig, $72.5 \%$ of the samples had a difference in cell number of less than $1 \log , 25 \%$ of less than 2 logs, and $2.5 \%$ of less than 2.5 logs for C. coli real-time PCR assay. For C. jejuni real-time PCR assay, the results obtained by real-time PCR matched equally the results obtained by culture: $67 \%$ of the samples had a difference in cell number of less than $1 \log$, 29\% of less than 2 logs, and $4 \%$ of less than 3 logs.

Analysis of field samples of naturally contaminated pigs No C. jejuni was identified among the faecal, feed, and environmental samples from the different pig herds by 


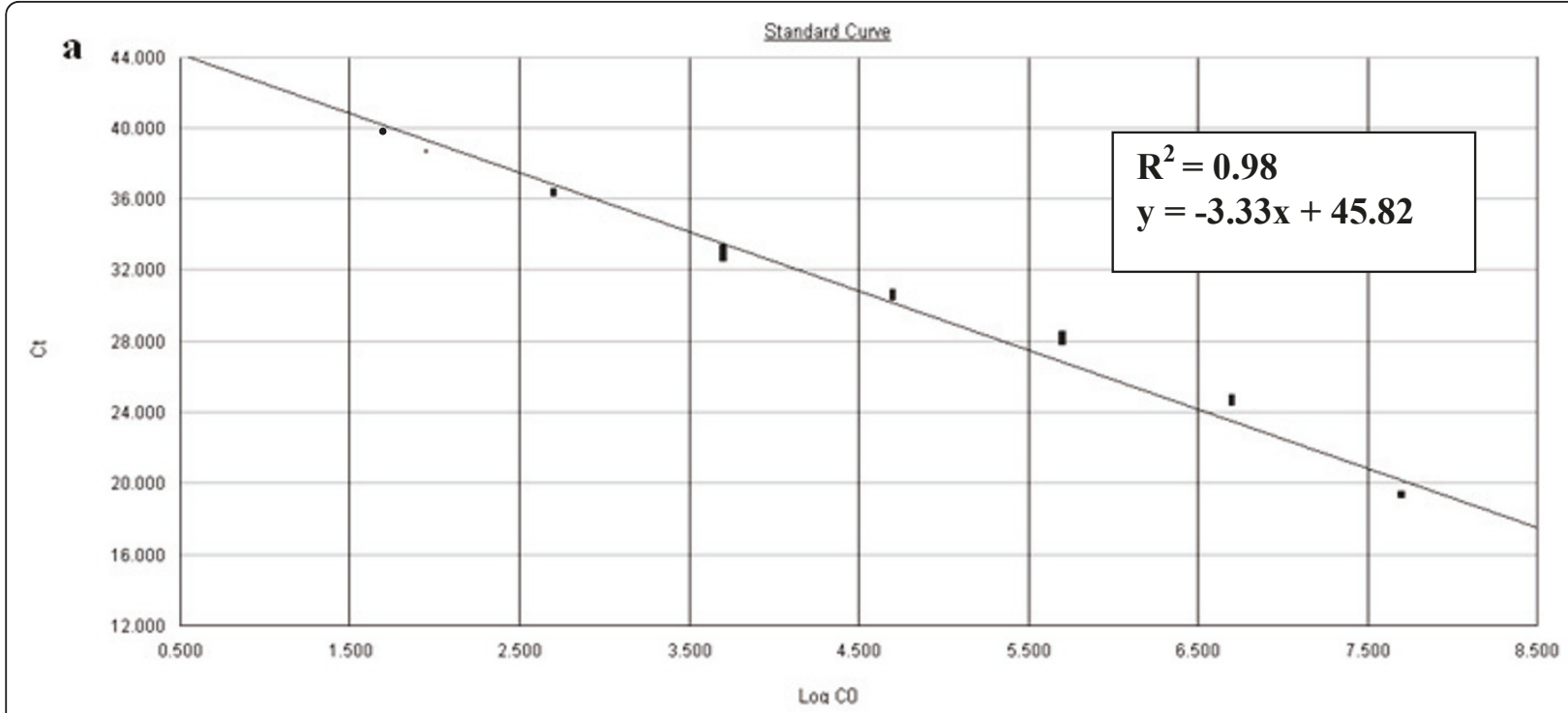

b

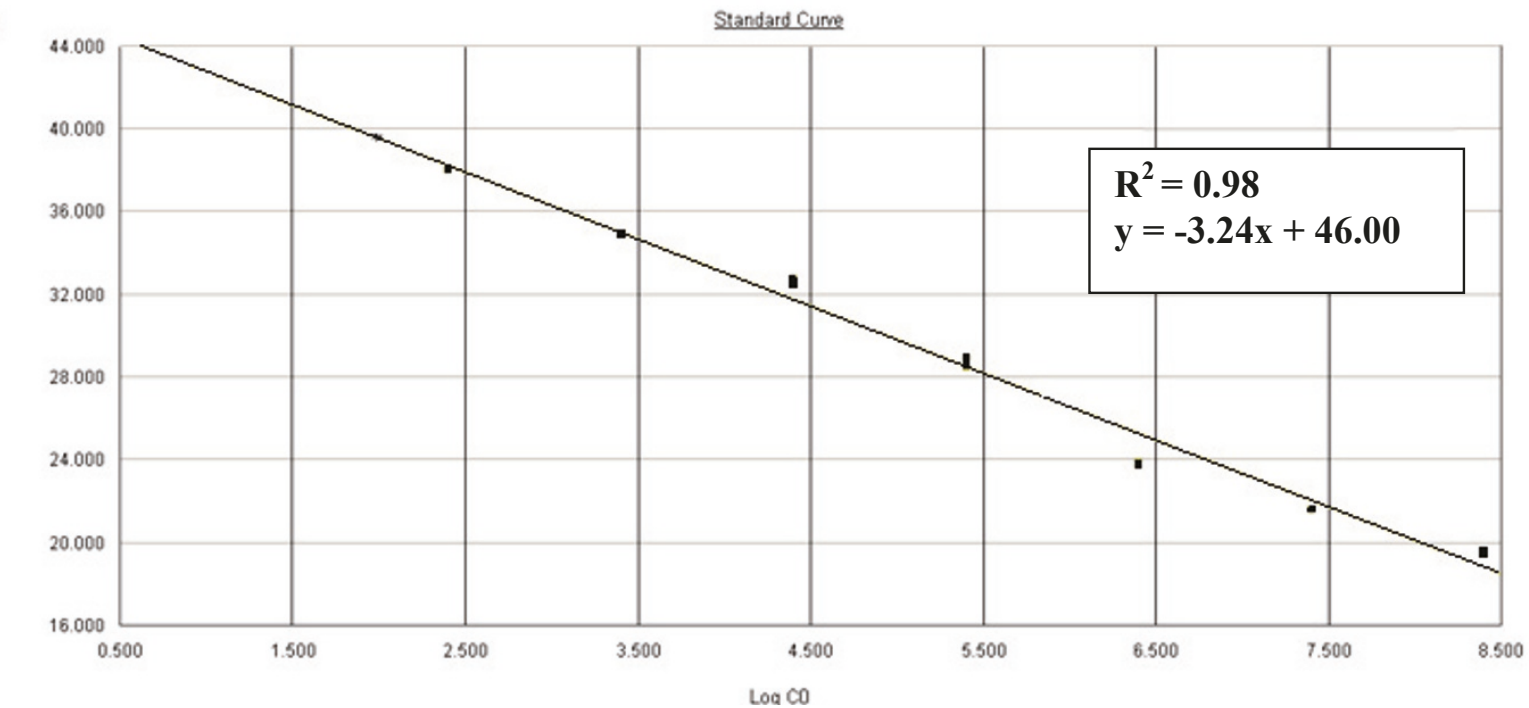

Figure 3 Dynamic range and sensitivity of the Campylobacter coli and Campylobacter jejuni real-time PCR assays for faecal samples Standard curves of DNA extracted from the Campylobacter-negative faecal samples spiked with 10-fold serial dilution of (a) C. coli CIP 70.81 suspension, ranging $2.5 \times 10^{2}$ to $2.5 \times 10^{7} \mathrm{CFU} / \mathrm{g}$ of faeces and (b) C. jejuni NCTC 11168 suspension, ranging $2.0 \times 10^{2}$ to $2.0 \times 10^{7} \mathrm{CFU} / \mathrm{g}$ of faeces, each dot representing the result of duplicate amplification of each dilution. The coefficients of determination $R^{2}$ and the slopes of the regression curve are indicated. The standard curve is obtained by correlation of the threshold cycle values (Ct) and log 10 input CFU/g of faeces (Log CO) from the amplification plot.

conventional PCR or by our C. jejuni real-time PCR assay. Conversely, all the Campylobacter tested were identified as C. coli by both methods.

The specificity and the sensitivity for the $C$. coli realtime PCR assay with the different field samples are reported in Table 4.

For the different field samples tested, the quantification results obtained by C. coli real-time PCR matched equally the results obtained by bacterial culture: $58 \%$ of the samples had a difference in cell number of less than $1 \log , 37 \%$ of less than 2 logs, and $5 \%$ of less than 3 logs.

\section{Discussion}

The real-time PCR asays developed in this study provide an effective, rapide, and sensitive alternative method to 
Table 3 Comparison of real-time PCR and microaerobic culture in faecal samples of experimentally infected pigs for the detection of (3.1) Campylobacter coli and (3.2) Campylobacter jejuni

\begin{tabular}{|c|c|c|c|c|c|}
\hline & & \multicolumn{4}{|c|}{ Microaerobic culture } \\
\hline & & & + & - & Total \\
\hline & & + & 40 & 1 & 41 \\
\hline \multirow[t]{3}{*}{ 3.1 Campylobacter coli detection } & Real-time PCR & - & 1 & 25 & 26 \\
\hline & & Total & 41 & 26 & 67 \\
\hline & & + & 24 & 1 & 25 \\
\hline \multirow[t]{2}{*}{ 3.2 Campylobacter jejuni detection } & Real-time PCR & - & 2 & 25 & 27 \\
\hline & & Total & 26 & 26 & 52 \\
\hline
\end{tabular}

3.1 Sensitivity $\mathrm{Se}=97.6 \%$, Specificity $\mathrm{Sp}=96.2 \%$, Kappa $\mathrm{K}=0.94$

3.2 Sensitivity Se $=92.3 \%$, Specificity $\mathrm{Sp}=96.2 \%$, Kappa $K=0.89$

culture-based methods for the detection and the quantification of C. coli and C. jejuni in pure cultures and in complex samples.

To use real-time PCR for quantitative measurements and to ensure a correct quantification, information on both linear range and amplification efficiency of the real-time PCR assay must be available. With a quantitative detection limit of 10 genome copies, an amplification efficiency of $99 \%$, and a linear range of seven to eight orders of magnitude, the C. coli and C. jejuni realtime PCR assays allowed a precise quantification of $C$. coli or $C$. jejuni DNA amounts extracted from pure culture preparations. The specificity of the assays was assessed (i) by the species-specific amplification of DNA from different field strains/isolates of $C$. coli and $C$. jejuni, and (ii) by the absence of amplification from DNA isolated from 30 pig faecal, feed, and environmental samples previously determined to be Campylobacterfree by culture. The real-time PCR assays were also shown to be highly specific since no PCR amplicons were detected when the method was applied to DNA from different bacterial reference strains, including different Campylobacter species, Campylobacter-related bacteria, and other bacteria. Both intra- and inter-assay coefficients of variation of the Ct values for the purified genomic DNA were satisfactorily low and in concordance with those reported for other molecular assays based on PCR amplification [35]. They confirmed the reliability and the accuracy of the technical setup over time and over the complete range of quantification.

The technique was developed to detect and quantify $C$. coli and/or C. jejuni directly in pig faecal, feed, and environmental samples. In order to determine the detection limits of C. coli and C. jejuni real-time PCR assays for field samples, Campylobacter-negative faecal samples were spiked with 10-fold dilutions of the Campylobacter suspensions of each reference strain (C. jejuni NCTC 11168 and C. coli CIP 70.81). Standard curves for environmental and feed samples were constructed in a similar way. The established C. coli and C. jejuni real-time PCR assays proved highly sensitive (with a quantitative detection limit of approximately $2.5 \times 10^{2} \mathrm{CFU} / \mathrm{g}$ of faeces, $1.3 \times 10^{2}$ $\mathrm{CFU} / \mathrm{g}$ of feed, and $1.0 \times 10^{3} \mathrm{CFU} / \mathrm{m}^{2}$ for the environmental samples) and were linear over a range of six orders of magnitude (from $2.0 \times 10^{2}$ to $2.0 \times 10^{7} \mathrm{CFU} / \mathrm{g}$ of faeces). Both intra- and inter-assay coefficients of variation of the Ct values for the DNA extracted from Campylobacternegative faecal samples did not differ significantly. This may indicate that the main reason for variation is not due to pipetting errors in setting up the PCR assay but may be caused by contaminants from the fecal samples. Nevertheless, we did not observe systematically lower $\mathrm{CV}$ values of intra- and inter-assay variations with purified genomic DNA. This does not support the hypothesis that inhibitors and contaminants may interfere with uniform and consistent dilution as well as the amplification of target DNA.

Samples tested in this study constitute complex biological substrates due to the presence of (i) numerous types of bacteria, (ii) different kinds of inhibitors, and (iii) food degradation products [36,37]. Moreover, contrary to faecal and caecal chicken samples [35,38], the consistency and the composition of pig faecal samples are highly variable and heterogeneous (i) between individuals, (ii) over time according to the age of the animals, and (iii) depending on the diet components in the same way as for cattle faeces $[39,40]$. In this study, we sampled faeces of sows, piglets, weaners, and finishers, exhibiting considerable heterogeneity (water content, presence of mucus, and fiber content). All these variables may have an impact on the DNA extraction process and inhibitor removal, affecting the quality and the quantity of DNA obtained, thereby limiting the sensitivity of molecular studies. The modified sample preparation procedure, which included (i) a large volume of faeces ( $5 \mathrm{~g}$ fresh weight), (ii) a boiling step known to remove inhibitors of the Taq polymerase [41], and (iii) the use of a DNA extraction kit, allowed a better homogenization of the faeces and achieved partial removal of inhibitors. No difference was noticed between real-time PCR assays and culture at both qualitative and 


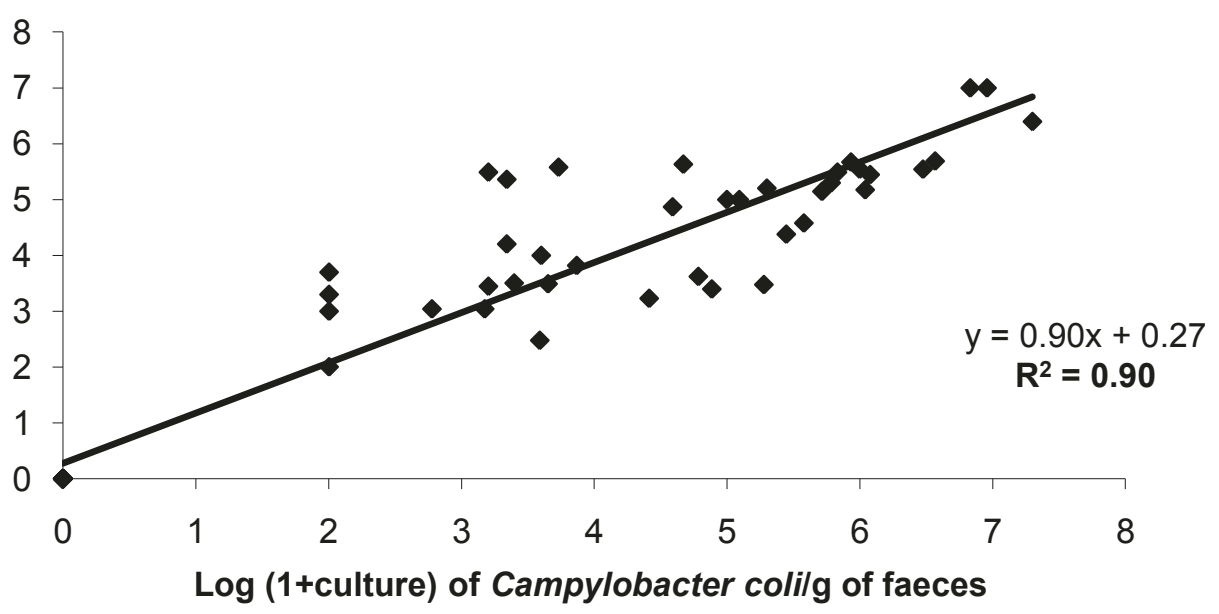

b

\section{$\log (1+P C R) C F U / g$ of faeces}

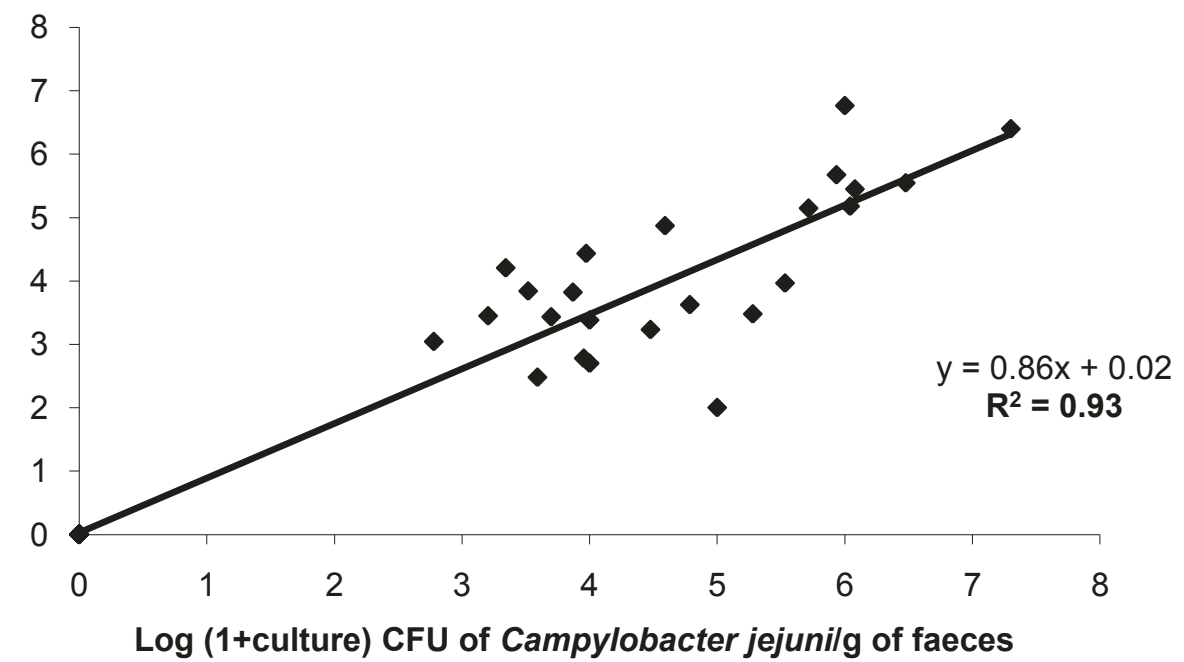

Figure 4 Correlation between real-time PCR and microaerobic culture for faecal samples of Campylobacter experimentally infected pigs. Scatter plot showing the differences and correlations between the real-time PCR and the microaerobic culture method for the faecal samples of pigs experimentally infected with Campylobacter for the detection of (a) C. coli and (b) C. jejuni. Data for Campylobacter-positive samples versus Campylobacter-negative samples by both methods fall close to the line equivalence: $\mathbf{a}$ - Campylobacter-positive $(\boldsymbol{n}=\mathbf{4 0})$ and

Campylobacter-negative $(\boldsymbol{n}=\mathbf{2 5})$ samples respectively with a coefficient of correlation of $0.90\left(R^{2}=0.90\right)$. b-Campylobacter-positive $(\boldsymbol{n}=\mathbf{2 4})$ and Campylobacter-negative $(\boldsymbol{n}=\mathbf{2 5})$ samples respectively with a coefficient of correlation of $0.93\left(R^{2}=0.93\right)$.

quantitative levels for faecal samples differing by the composition, the consistency, or the age of the sampled animal (data not shown). Nevertheless, in this study, the potential presence of PCR inhibitory compounds was in parallel assessed with the use of an internal bacterial control of extraction and amplification in a separate real-time PCR test [34]. Inhibitors of real-time PCR were identified only in $4 \%$ of the examined samples, which were consequently removed from the quantification study. Moreover, the DNA extraction step reproducibility, an important parameter when evaluating the DNA purification [42], was satisfactory proved with the low $\mathrm{CV}$ values of the inter-assay variability including the DNA extraction procedure. 
Table 4 Comparison of Campylobacter coli real-time PCR and microaerobic culture in (4.1) faecal, (4.2) feed, and (4.3) environmental samples of naturally contaminated pigs

\begin{tabular}{|c|c|c|c|c|c|}
\hline & & & \multicolumn{2}{|c|}{ Microaerobic culture } & \multirow[b]{2}{*}{ Tota } \\
\hline & & & + & - & \\
\hline \multirow[t]{3}{*}{ 4.1 Campylobacter coli detection in faecal samples } & & + & 125 & 1 & 126 \\
\hline & Real-time PCR & - & 3 & 17 & 20 \\
\hline & & Total & 128 & 18 & 146 \\
\hline \multirow[t]{3}{*}{ 4.2 Campylobacter coli detection in feed samples } & & + & 21 & 1 & 22 \\
\hline & Real-time PCR & - & 2 & 26 & 28 \\
\hline & & Total & 23 & 27 & 50 \\
\hline \multirow[t]{3}{*}{ 4.3 Campylobacter coli detection in environmental samples } & & + & 34 & 2 & 36 \\
\hline & Real-time PCR & - & 3 & 47 & 50 \\
\hline & & Total & 37 & 49 & 86 \\
\hline
\end{tabular}

4.1 Sensitivity Se $=97.7 \%$, Specificity $\mathrm{Sp}=94.4 \%$, Kappa $\mathrm{K}=0.96$

4.2 Sensitivity $\mathrm{Se}=91.3 \%$, Specificity $\mathrm{Sp}=96.2 \%$, Kappa $\mathrm{K}=0.89$

4.3 Sensitivity Se $=91.9 \%$, Specificity Sp $=95.9 \%$, Kappa $K=0.89$

Three faecal samples of experimentally infected pigs, detected as negative by PCR and direct streaking, were positive by culture after an enrichment step (one out of 41 and two out of 26 for C. coli and C. jejuni realtime PCR assays respectively) leading to a sensitivity of $97.6 \%$ and $92.3 \%$. Although the internal control was positive, we cannot exclude the hypothesis of inhibition of C. coli and C. jejuni amplification. Indeed, it was previously reported that some PCR primers are more markedly affected than others by impurities present in DNA preparations [43,44]. Moreover, it could be false negative PCR samples, which have been below the detection limit of the two real-time PCR assays. Genetic variability among the isolates of Campylobacter spp., which has been demonstrated previously [45-47], can also affect the efficacy of a PCR if changes occur within one or both of the binding sites $[17,46]$. The enrichment step enhanced the sensitivity of the bacteriological method by lowering the detection limit. Nevertheless, even if it is helpful for poorly contaminated samples, researchers have reported several cases in which C. jejuni signals detected by direct PCR disappeared after enrichment. Conversely $C$. coli signals were maintained when present before enrichment, or else became detectable when undetectable before enrichment $[24,48]$. This suggests that the enrichment media may favour the growth of one Campylobacter species comparatively to the other [49].

Furthermore, for the experimentally infected pigs, only one culture-negative faecal sample was positive by realtime PCR for each target leading to a specificity of 96.2\% for both C. coli and C. jejuni real-time PCR assays. These results may be due to the presence of viable but nonculturable (VBNC) forms or dead bacteria cells, since DNA-based tests detect all DNA of the extract from live as well as dead bacteria $[27,29,50]$. If this is the case, it is another advantage of these realtime PCR assays as Campylobacter cells in a VBNC state may potentially be still infectious [18,51]. The bacteriological method may also explain these results given that the sensitivity of culture may vary depending on the Campylobacter spp. due to differences in susceptibility to antibiotics present in selective agar [52]. Moreover, in pig faceal and environmental samples, the enrichment of $C$. jejuni could be difficult due to the presence of a high background flora and due to the more numerous $C$. coli quantity [20].

Finally, for the faecal samples of experimentally infected pigs, we observed a good correlation at the quantitative level between culture enumeration and quantitative PCR for both $C$. coli and C. jejuni real-time PCR assays $\left(R^{2}=0.90\right.$ and $R^{2}=0.93$ respectively). Among the PCR-culture positive samples, the real-time PCR quantification seems to be accurate compared to the culture enumeration used as a gold standard. Indeed, more than $95 \%$ of the samples with a difference in cell number of less than 2 logs, of these $72.5 \%$ and 67\% less than $1 \log$ respectively for $C$. coli and C. jejuni real-time PCR assays. The observed discrepancy might be due to the possible presence of VBNC forms, dead cells and antagonistic bacterial species. Another possibility could be the impact of dilution factors used for quantitative culture or an insufficient homogenization of the samples. This method provides a mean to identify and quantify at the species level C. coli and C. jejuni directly from faecal, feed, and environmental samples without requiring an enrichment step. For the different field samples tested, the qualitative data (specificity and sensitivity) as well as the quantification results obtained by C. coli real-time PCR matched equally the results obtained by bacterial culture. In this study, no $C$. jejuni was identified among the faecal, feed, and environmental 
samples from the different pig herds by conventional PCR or by our C. jejuni real-time PCR assay. Conversely, all the Campylobacter tested were identified as $C$. coli by both methods. In France, pigs were found to be almost always contaminated by C. coli, these first results confirmed this predominance. Nevertheless, given that we can find both species in pigs [10,12-14], these realtime PCR assays allow a direct and rapid investigation of the carriage and the excretion of C. coli and C. jejuni in conventional pigs.

\section{Conclusion}

The real-time PCR assays for C. coli and C. jejuni described in this study have several advantages over culture-based techniques. These include allowing a large increase in throughput, enabling simultaneous processing of several samples (the real-time PCR can be run in a 96-well format and many steps in the assay can be automated), and reducing the total time required for analysis. The identification at the species level and the quantification on the entire DNA extracted from faecal, feed, and environmental samples is a new tool to enhance our understanding of the epidemiology of Campylobacter. In terms of risk assessment, this ability to differentiate and quantify these two species permits a more precise description of the carriage and excretion of $C$. coli and C. jejuni by livestock animals.

\section{Methods}

\section{Bacterial strains and culture conditions}

Different Campylobacter spp., Helicobacter, Wolinella, and Arcobacter reference strains were used to test the specificity of primers and probes for real-time PCR identification and differentiation of C. coli and C. jejuni (Table 1). In addition, we have tested $50 \mathrm{C}$. jejuni and 75 C. coli isolates (from human, poultry, and pig origin) as well as other enteric bacteria (clinical isolates and reference strains) selected from our in-house collection, the collection of the French Agency for Food, Environmental and occupational Health and Safety (Anses, Ploufragan), and the collection of the French National Reference Center for Campylobacter and Helicobacter (CNR-CH, Bordeaux). Strains were stored at $-80^{\circ} \mathrm{C}$ in brain heart infusion broth (Difco, Detroit, Michigan) containing 20\% (v/v) glycerol. Moreover, for the realtime PCR reactions, we used the two reference strains C. jejuni NCTC 11168 and C. coli CIP 70.81 as positive controls as well as Listeria monocytogenes ATCC 19115 and Escherichia coli CIP V517 as negative controls. Campylobacter strains were grown at 25,37 or $41.5^{\circ} \mathrm{C}$ for $48 \mathrm{~h}$ in a microaerobic atmosphere $\left(5 \% \mathrm{O}_{2}, 10 \%\right.$ $\mathrm{CO}_{2}, 85 \% \mathrm{~N}_{2}$ ) on Karmali agar plates (Oxoid, Dardilly, France). Arcobacter, Helicobacter, and Wolinella were grown at $37^{\circ} \mathrm{C}$ for $48 \mathrm{~h}$ on Columbia Blood agar plates
(Oxoid, Dardilly, France) with 5\% of defibrinated sheep blood (AES Chemunex, Combourg, France) and Enterobacter aerogenes on Purple Lactose agar plates (BCP, AES Chemunex, Combourg, France) for $24 \mathrm{~h}$. All the other bacteria listed in Table 1 were grown under appropriate culture conditions at 30 or $37^{\circ} \mathrm{C}$ for $24 \mathrm{~h}$ on Tryptone soja agar yeast extract plates (TSAYE Oxoid, Dardilly, France).

\section{DNA extraction from bacterial cultures}

Genomic DNA from each bacterial culture was extracted using the Nucleospin ${ }^{\circledR}$ Tissue mini-kit (Macherey Nagel, Hoerdt, France) and according to the manufacturer's instructions. The concentration of isolated double stranded DNA was determined by measuring the optical density at $260 \mathrm{~nm}$ with the Spectronic ${ }^{B}$ Genesys $^{\mathrm{TM}} 5$ (Spectronic Instruments Inc., New York, USA). The purity was assessed by the examination of 260/280 nm optical density ratios [53]. All DNA samples classified as pure (i.e. having a $260 / 280 \mathrm{~nm}$ optical density ratio between 1.8 and 2.0 ) were adjusted to 20 $\mathrm{ng} \mu \mathrm{L}^{-1}$ in TE buffer $(10 \mathrm{mmol}$ Tris- $\mathrm{HCl}, 1 \mathrm{mmol}$ EDTA, $\mathrm{pH}$ 7.6) and stored at $-20^{\circ} \mathrm{C}$ until required for analysis.

\section{Construction of the standard curves with purified genomic DNA}

Total genomic DNA of C. jejuni NCTC 11168 and C. coli CIP 70.81 cultures were extracted as described above. The genome copy numbers of $C$. jejuni and $C$. coli in 100 ng of DNA (for one PCR reaction) was calculated on the basis of the genome size (1 $640 \mathrm{Kbp}$ for C. jejuni, $1860 \mathrm{Kbp}$ for C. coli) [54-56] and was equal to $5.2 \times 10^{7}$ and $4.6 \times 10^{7}$ copies respectively. After DNA quantitation by spectrofotometrical analysis with the Spectronic ${ }^{\circledR}$ Genesys $^{\text {TM }} 5$, 10-fold dilutions of each extract were produced in TE buffer, representing $10^{1}$ to $10^{8}$ genome copies of $C$. jejuni per $5 \mu \mathrm{L}$ of template (PCR reaction) and $0.3 \times 10^{1}$ to $3.0 \times 10^{8}$ genome copies of C. coli per $5 \mu \mathrm{L}$ of template (PCR reaction). Moreover, a standard curve with roughly equal genome copies of $C$. jejuni and C. coli together was produced for each PCR assay. Serial DNA dilutions were aliquoted: some were stocked at $4^{\circ} \mathrm{C}$ to be use directly, others were stored frozen at $-20^{\circ} \mathrm{C}$ and thawed once for use.

\section{Sample collection \\ Campylobacter-negative samples}

Fifteen Campylobacter-negative faecal samples were obtained from specific pathogen-free (SPF) sows and piglets from the high-security barn at the Anses centre (Ploufragan, France). Moreover, five Campylobacternegative feed samples and 10 Campylobacter-negative environmental samples were collected from the same 
high-security barns. These samples were used to test the specificity and/or the analytical sensitivity of the realtime PCR assays. For the environmental samples, each pen of pigs was sampled on the bottom of the wall and pen partitions using swabs (sterile square pieces of cotton cloth $(32.32 \mathrm{~cm})$ moistened with isotonic saline solution) (Sodibox, La Forêt-Fouesnant, France). The swabs were placed in a sterile bag before to be analyzed.

\section{Additional faecal, feed, and environmental samples}

Faecal samples were obtained from both pigs experimentally inoculated with $5 \times 10^{7} \mathrm{CFU}$ of Campylobacter ( $n=119$, respectively $67 \mathrm{C}$. coli and 52 C. jejuni faecal samples) [57] and naturally contaminated pigs in five conventional herds $(n=146)$. Given that pig faeces can be highly heterogeneous, rectal faecal samples were collected individually from naturally contaminated (i) sows, (ii) pigs aged three to 16 weeks, and (iii) piglets aged one to three weeks. Additionally, in the five conventional herds, 86 environmental swabs of pig pens (either empty or with animals) and 50 feed samples were collected. The swabbed surface area was measured each time.

\section{Sample processing and experimental conditions}

All samples were examined within four hours after sampling for Campylobacter spp. quantification by conventional culture and for species-identification by the PCR described by Denis et al. (1999) [24] as well as for species-specific quantification by real-time PCR assays. All animals of this study were housed and treated in accordance with the regulations of the local veterinary office (Direction des Services Vétérinaires des Côtes d'Armor, France). The animal experimention was carried out following the international recognized guidelines. All the animals were reared in isolation rooms with controlled air flow [57].

\section{DNA preparation for real-time PCR-based quantification}

DNA isolation from the faecal, feed, and environmental samples was performed using a modified extraction protocol of the Nucleospin ${ }^{\circledR}$ Tissue mini-kit (Macherey Nagel, Hoerdt, France) with a preliminary step of boiling to remove inhibitors of the Taq polymerase [41]. Five grams of sample (faeces or feed) were diluted in $5 \mathrm{~mL}$ of sterile water (for smaller amounts, an equivalent quantity of sterile water $(\mathrm{w} / \mathrm{w})$ was added). The environmental swabs, placed into sterile bags, were stomached for $2 \mathrm{~min}$ with $10 \mathrm{~mL}$ of sterile water. The sample solutions of faeces, feed, and swabs were boiled for $10 \mathrm{~min}$, chilled on ice, and centrifuged (8000 $\mathrm{g}, 5 \mathrm{~min}$ ). For each sample, $250 \mu \mathrm{L}$ of supernatant was extracted using the Nucleospin ${ }^{\circledR}$ Tissue mini-kit according to the manufacturer's instructions. Finally, DNA preparations, eluted in $100 \mu \mathrm{L}$ of elution buffer purchased in the kit, were stored at $+4^{\circ} \mathrm{C}$ prior to use.

\section{Control of PCR inhibition}

To test the presence of PCR inhibitors in the DNA isolated from the samples, a fixed amount of the bacterium Yersinia ruckeri was added to each sample before the DNA extraction. This internal bacterial amplification and extraction control was quantified in a separate well using a real-time PCR test described in a previous work [34]. Samples with PCR inhibition were then removed for the rest of the study.

\section{Enumeration of Campylobacter spp. and species identification}

Ten grams of fresh faeces, ten grams of feed, and the environmental swabs were vortexed in $90 \mathrm{~mL}$ of Preston broth (Oxoid, Dardilly, France) with a Preston antibiotic supplement (Oxoid, Dardilly, France) (for rectal swabs, 9 $\mathrm{mL}$ of Preston broth was added to one gram of faeces). For Campylobacter numeration, $100 \mu \mathrm{L}$ of a ten-fold dilution serie $\left(10^{-1}\right.$ to $\left.10^{-5}\right)$ were plated both on Karmali agar (Oxoid, Dardilly, France) and on Butzler agar (Oxoid, Dardilly, France) and incubated for 24 to $72 \mathrm{~h}$ at $41.5^{\circ} \mathrm{C}$ in microaerobic conditions. To promote the detection of Campylobacter in samples harbouring less than 100 Colony Forming Unit of Campylobacter per gram of faeces (CFU/g of faeces), a second plating was carried out $24 \mathrm{~h}$ after broth enrichment and incubated 48 h. Thermophilic Campylobacter were cultured at $41.5^{\circ} \mathrm{C}$ in microaerobic conditions. For direct streaking and selective enrichment, the Campylobacter suspect colonies on Karmali or Butzler plates were confirmed by microscopy (cell morphology) and conventional PCR [24]). The number of CFU/g of faeces or feed as well as the number of $\mathrm{CFU} / \mathrm{m}^{2}$ for the environmental samples were thus calculated. Finally, material from Campylobacter suspect colonies was suspended in TE buffer and subdued to DNA extraction and the species-specific PCR described by Denis et al. (1999) [24] for differentiation between C. coli and C. jejuni.

\section{Real-time PCR primers and probes}

To detect $C$. jejuni and $C$. coli, we have used sequences described by Lagier et al. (2004) [33], which are based (i) on the single-copy hipO gene (benzoylglycine amidohydrolase) responsible for the hippurate activity exclusively found within the $C$. jejuni genome, and (ii) on the single-copy $g l y A$ gene (serine hydroxymethyltransferase) in an unique nucleotide region within the C. coli glyA open reading frame identified as specific for $C$. coli [58] (Table 5).

To optimize the real-time PCR reaction and to improve the specificity and the mismatch discrimination, shorter Minor Groove Binder (MgB) probes have been designed [59-62]. At the 5'end, the C. coli probe was linked to the fluorophore FAM and the $C$. jejuni probe 
to the fluorophore VIC. The C. jejuni and C. coli species-specific primers and TaqMan ${ }^{\circledR} \mathrm{MgB}$ probe sets were thus designed with Primer Express software version 2.0 (Applied Biosystems, Foster city, CA, USA) according to the recommendations of the manufacturer (Table 5). This software was used to choose the best combinations of each primers-probe set values. Finally, the selected primers and probes were checked for homology to non-target sequences by a search with the BLAST program of the National Center for Biotechnology Information (NCBI). Primers and MgB probes were synthesized by Applied Biosystems and stored at $-20^{\circ} \mathrm{C}$ prior to use.

\section{Real-time PCR amplification}

Reactions were done in $20 \mu \mathrm{L}$ PCR mixtures containing $10 \mu \mathrm{L}$ of $1 \mathrm{X}$ Taqman Universal PCR Mastermix (AmpliTaq Gold ${ }^{\mathrm{TM}}$ DNA polymerase, dNTPs, Passive reference (ROX), and optimised buffer components including 5 $\mathrm{mM} \mathrm{MgCl} 2$ ), $400 \mathrm{nM}$ of each primer (glyA-R and gly A-F for C. coli real-time PCR assay, hip O-R and hip O-F for C. jejuni real-time PCR assay), $200 \mathrm{nM}$ of the probe (gly A-P and hip $\mathrm{O}-\mathrm{P}$ respectively), and $5 \mu \mathrm{L}$ of template DNA. The thermal cycle protocol used was the following: activation of the Taq DNA polymerase at $95^{\circ} \mathrm{C}$ for $10 \mathrm{~min}$, then 45 or 48 cycles of $15 \mathrm{~s}$ at $95^{\circ} \mathrm{C}$ and $60 \mathrm{~s}$ at $60^{\circ} \mathrm{C}$. Thermal cycling, fluorescent data collection, and data analysis were carried out with the ABI PRISM ${ }^{\circledR}$ 7300 Sequence Detection System (Applied Biosystems) according to the manufacturer's instructions. Fluorescence of FAM and VIC was measured at their respective wavelengths during the annealing/elongation step of each cycle. After real-time data acquisition, the baseline cycles for the FAM and VIC signals were set from cycle three to three cycles below the cycle at which the first signal appeared and the threshold value at the point at which the fluorescence exceeded 10 times the standard deviation of the mean baseline emission. The threshold cycle $(\mathrm{Ct})$ is the first PCR cycle at which a statistically significant increase in fluorescent signal is detected. All reactions were carried out alongside a non template control containing all reagents except DNA, positive controls containing DNA from reference strains $(C$. jejuni NCTC 11168 and/or C. coli CIP 70.81), and negative controls containing DNA from Listeria monocytogenes ATCC 19115 and from Escherichia coli CIP V517. All the DNA extractions were done as described before. Each control was run in triplicate and each sample in duplicate.

\section{Evaluation of performance of the real-time PCR assays Specificity and sensitivity}

The specificity of each real-time PCR assay was first assessed with purified genomic DNA preparations (about $10^{6}$ genome copies per PCR reaction) of different bacterial strains (Table 1) and then with DNA extracted from 30 Campylobacter-negative faecal, feed, and environmental samples as defined above. This screening strategy, described previously by Lagier et al. (2004) [33], ensure the specificity of the primers and probes for C. jejuni and C. coli only in field samples. Doublestranded DNA extracted from the 30 Campylobacternegative faecal, feed, and environmental samples was examined in duplicate with each real-time PCR assay.

The sensitivity for each PCR assay was determined using the standard curves prepared with purified genomic DNA of cultures of C. jejuni NCTC 11168 and $C$. coli CIP 70.81, ranging from $10^{1}$ to $10^{8}$ genome copies per $5 \mu \mathrm{L}$ of template (PCR reaction). In order to mimic realistic conditions and to determine the detection limits of C. coli and C. jejuni real-time PCR assays for field samples, different standard curves were prepared to quantify C. coli or C. jejuni in faecal, feed, and environmental samples. Campylobacter-negative faecal samples were spiked with 10 -fold dilutions series of viable suspensions of each reference strain (C. jejuni NCTC 11168 and C. coli CIP 70.81), ranging from $10^{1}$ to $10^{8}$ Colony Forming Units per gram of faeces (CFU/g).

Table 5 PCR primers and probes used in the species-specific real-time PCR assays

\begin{tabular}{|c|c|c|c|c|}
\hline Primer or Probe ${ }^{a}$ & Nucleotide sequence $5^{\prime}-3^{\prime}$ & Location within target & Origin & Target Gene detected $^{b}$ \\
\hline glyA-F forward & F: AAACCAAAGCTTATCGTGTGC & $297-320$ & This study & \\
\hline glyA- $\mathrm{R}$ reverse & R: AGTGCAGCAATGTGTGCAATG & $422-359$ & Lagier et al. (2004) & Campylobacter coli glyA gene (125 bp) \\
\hline glyA-P MGB Probe & P: FAM-CAACTTCATCCGCAAT & $346-330$ & This study & \\
\hline hipO-F forward & F: CTTGCGGTCATGCTGGACATAC & $340-360$ & This study & \\
\hline hipO-R reverse & R: AGCACCACCCAAACCCTCTTCA & $464-444$ & This study & Campylobacter jejuni hipO gene (124 bp) \\
\hline hipO-P MGB Probe & P: VIC-ATTGCTTGCTGCAAAGT & $424-409$ & This study & \\
\hline
\end{tabular}

$\mathrm{bp}$, length in base pairs of the species specific PCR products

${ }^{a}$ Primers and probes were designed by using the program Primer Express version 2.0 (Applied Biosystems, Foster city, CA, USA). The TaqMan ${ }^{(\mathbb{R}}$ MGB probes were dual-labelled with either fluorescent reporter dyes FAM (6-carboxyfluorescein, $C$. coli specific probe) or VIC (C. jejuni specific probe) on the $5^{\prime}$ end, and quenched by a non fluorescent quencher associated with a minor groove binder at the 3'end (Applied Biosystems).

${ }^{\text {b}}$ The nucleotide sequences were retrieved from the GenBank ${ }^{\mathrm{TM}}$ sequence database http://www.ncbi.nlm.nih.gov/Genbank/index.html under accession numbers: [GenBank: Z36940] for C. jejuni hipO gene and [GenBank: AF136494] for C. coli glyA gene. 
Standard curves for environmental and feed samples were constructed in a similar way. DNA was extracted from each of the spiked samples and tested in real-time PCR, where the standard curves were created automatically by the ABI PRISM ${ }^{\circledR} 7300$ Sequence Detection System Software by plotting the $\mathrm{Ct}$ values against each standard dilution of known concentration.

\section{Intra- and inter- assay variabilities}

The assay variability was established by repeatedly testing samples containing several concentrations of $C$. coli and $C$. jejuni spanning the whole range covered by each real-time PCR in different assays (10 consecutive runs) and within an assay (10 duplicates in the same assay), in order to calculate the inter- and intra-assay coefficients of variation $(\mathrm{CV})$ for the $\mathrm{Ct}$ values experimentally determined, as previously described [63].

To assess the intra-assay variation, each dilution of purified genomic DNA of cultures from $C$. jejuni NCTC 11168 and C. coli CIP 70.81 from approximately $10^{1}$ to $10^{8} \mathrm{CFU}$ were measured 10 times each within one PCR run. The inter-assay variation was evaluated with the same different dilutions of purified genomic DNA in 10 independent PCR experiments on different days (10 different runs). For each PCR run, each dilution point was tested in duplicate and the mean standard curve was used for quantity estimation.

To assess the method with field samples, the values for the intra- and inter-assay variations of the real-time PCR assays were obtained with the DNA extracted from the Campylobacter-negative spiked samples. To assess the intra-assay variation, DNA extracted from the Campylobacter-negative faecal samples spiked with 10-fold dilutions of the Campylobacter suspensions, ranging from $2.5 \times 10^{7}$ to $2.5 \times 10^{2} \mathrm{CFU}$ of $C$. coli/g of faeces and from $2.0 \times 10^{7}$ to $2.0 \times 10^{2} \mathrm{CFU}$ of $C$. jejuni/g of faeces, were measured 10 times each within one realtime PCR run. The inter-assay variation was evaluated with different dilutions of DNA extracted each time with a specific extraction from the Campylobacter-negative spiked faecal samples in 10 independent real-time PCR experiments on different days. For each real-time PCR run (C. coli and C. jejuni real-time PCR assays), each dilution point was tested in duplicate and the mean standard curves were used for quantity estimation. The CV of the Ct values were calculated for the ten different inter-assay experiments. They illustrate the variability of the $\mathrm{Ct}$ values obtained between experiments including the specific DNA extraction procedure and the amplification step.

\section{Use of the standard curves}

The standard curves were thus used (i) to evaluate the sensitivity of the real-time PCR assays, (ii) to assess the intra- and inter-assay variabilities, and (iii) to allow a reliable quantification of C. jejuni and C. coli in pure cultures or in the field samples.

\section{Statistical analysis}

PCR amplification efficiency (E) was estimated using the slope of the standard curve and the formula $E=10^{(-1 /}$ slope) -1 . A reaction with $100 \%$ efficiency will generate a slope of -3.32. Data analysis was performed using the SDS software (Applied Biosystems).

The 119 field samples from the experimental infection were evaluated in parallel with the real-time PCR assays and the bacterial culture described in this study. All data analyses were performed with Microsoft excel and SAS Systems version 8 (SAS, Cary, N.C.). Specificity and sensitivity were assessed using the bacterial culture as a gold standard. The sensitivity was calculated as $a /(a+c)$, where $a$ is the number of samples found positive by both real-time PCR and bacterial culture (direct inoculation or after selective enrichment) and $c$ is the number of samples positive by bacterial culture but negative by real-time PCR. The specificity was calculated as $d /(b+d)$, where $d$ is the number of samples negative by both methods and $b$ is the number of samples positive by real-time PCR but negative by bacterial culture. Kappastatistic was used to measure the agreement between the microaerobic cultivation and each species-specific real-time PCR assay [64].

\section{Acknowledgements}

The authors thank Sebastien Tessier for technical assistance during his practice training period and the staff of the BioEpAR and MAE units at the Veterinary School of Nantes, notably Jean-Yves Audiart, Françoise Armand, Emmanuelle Blandin, and Françoise Leray.

We thank especially Francis Mégraud and Philippe Lehours of the French National Reference Center for Campylobacter and Helicobacter (Bordeaux, France) for providing us reference strains from their collection and field strains from clinical cases.

This work was supported by grants from INRA, Anses, and the Region Pays de La Loire.

\section{Author details}

'LUNAM Université, Oniris, UMR 1300 Biologie, épidémiologie et analyse des risques, Nantes, F-44307, France. ${ }^{2}$ INRA, Nantes, F-44307, France. ${ }^{3}$ Anses, French Agency for Food, Environmental and occupational Health and Safety, Unité Hygiène et Qualité des Produits Avicoles et Porcins, BP 53, Ploufragan, F-22440, France.

\section{Authors' contributions}

MLM participated in the design of the study, the collection of study samples, and in the microbiological analysis; carried out the molecular genetic studies, designed the specific oligonucleotides, participated in the sequence alignment, and drafted the manuscript. MD was responsible for the experimental infection, participated in the collection and microbiological analysis of study samples, and helped to draft the manuscript. FB performed the statistical analysis, and helped to draft the manuscript. HS helped to draft the manuscript. CB participated in the study conception and coordination, provided guidance during all parts of the work, and helped to draft the manuscript. All authors read and approved the final manuscript.

Received: 14 October 2010 Accepted: 22 May 2011

Published: 22 May 2011 


\section{References}

1. Moore JE, Corcoran D, Dooley JS, Fanning S, Lucey B, Matsuda M, McDowell DA, Megraud F, Millar BC, O'Mahony R, O'Riordan L, O'Rourke M, Rao JR, Rooney PJ, Sails A, Whyte P: Campylobacter. Vet Res 2005, 36(3):351-382

2. EFSA: The Community Summary Report on Trends and Sources of Zoonoses, Zoonotic Agents, Antimicrobial Resistance and Foodborne Outbreaks in the European Union in 2006. The EFSA Journal 2007, 130.

3. Skirrow MB: Epidemiology of Campylobacter enteritis. Int J Food Microbiol 1991, 12(1):9-16

4. Gilpin BJ, Scholes P, Robson B, Savill MG: The transmission of thermotolerant Campylobacter spp. to people living or working on dairy farms in New Zealand. Zoonoses Public Health 2008, 55(7):352-360.

5. Ahmed W, Sawant S, Huygens F, Goonetilleke A, Gardner T: Prevalence and occurrence of zoonotic bacterial pathogens in surface waters determined by quantitative PCR. Water Res 2009, 43(19):4918-4928.

6. Newell DG, Fearnley C: Sources of Campylobacter colonization in broiler chickens. Appl Environ Microbiol 2003, 69(8):4343-4351.

7. Nielsen EM, Engberg J, Madsen M: Distribution of serotypes of Campylobacter jejuni and Campylobacter coli from Danish patients, poultry, cattle and swine. FEMS Immunol Med Microbiol 1997, 19(1):47-56.

8. Petersen L, Nielsen EM, On SL: Serotype and genotype diversity and hatchery transmission of Campylobacter jejuni in commercial poultry flocks. Vet Microbiol 2001, 82(2):141-154.

9. Boes J, Nersting L, Nielsen EM, Kranker S, Enoe C, Wachmann HC, Baggesen DL: Prevalence and diversity of Campylobacter jejuni in pig herds on farms with and without cattle or poultry. J Food Prot 2005, 68(4):722-727.

10. Jensen AN, Dalsgaard A, Baggesen DL, Nielsen EM: The occurrence and characterization of Campylobacter jejuni and Campylobacter coli in organic pigs and their outdoor environment. Vet Microbiol 2006, 116(13):96-105.

11. Oporto B, Esteban JI, Aduriz G, Juste RA, Hurtado A: Prevalence and strain diversity of thermophilic Campylobacters in cattle, sheep and swine farms. J Appl Microbiol 2007, 103(4):977-984

12. Harvey RB, Young CR, Ziprin RL, Hume ME, Genovese KJ, Anderson RC, Droleskey RE, Stanker LH, Nisbet DJ: Prevalence of Campylobacter spp. isolated from the intestinal tract of pigs raised in an integrated swine production system. J Am Vet Med Assoc 1999, 215(11):1601-1604.

13. Young CR, Harvey R, Anderson R, Nisbet D, Stanker LH: Enteric colonisation following natural exposure to Campylobacter in pigs. Res Vet Sci 2000 68(1):75-78.

14. Mdegela RH, Laurence $K$, Jacob $P$, Nonga HE: Occurrences of thermophilic Campylobacter in pigs slaughtered at Morogoro slaughter slabs, Tanzania. Trop Anim Health Prod 2010.

15. Miller RS, Miller WG, Behringer M, Hariharan H, Matthew V, Oyarzabal OA: DNA identification and characterization of Campylobacter jejuni and Campylobacter coli isolated from caecal samples of chickens in Grenada. J Appl Microbiol 2009, 108(3):1041-1049.

16. Corry JE, Post DE, Colin P, Laisney MJ: Culture media for the isolation of Campylobacters. Int J Food Microbiol 1995, 26(1):43-76.

17. On SL: Identification methods for Campylobacters, Helicobacters, and Related Organisms. Clin Microbiol Rev 1996, 9(3):405-422

18. Murphy C, Carroll C, Jordan KN: Environmental survival mechanisms of the foodborne pathogen Campylobacter jejuni. J Appl Microbiol 2006, 100(4):623-632.

19. Steinhauserova I, Ceskova J, Fojtikova K, Obrovska I: Identification of thermophilic Campylobacter spp. by phenotypic and molecular methods. J Appl Microbiol 2001, 90(3):470-475.

20. Jensen AN, Andersen MT, Dalsgaard A, Baggesen DL, Nielsen EM: Development of real-time PCR and hybridization methods for detection and identification of thermophilic Campylobacter spp. in pig faecal samples. J Appl Microbiol 2005, 99(2):292-300.

21. Debruyne L, Samyn E, De Brandt E, Vandenberg O, Heyndrickx M, Vandamme P: Comparative performance of different PCR assays for the identification of Campylobacter jejuni and Campylobacter coli. Res Microbiol 2008, 159(2):88-93.

22. Persson S, Olsen KEP: Multiplex PCR for identification of Campylobacter coli and Campylobacter jejuni from pure cultures and directly on stool samples. J Med Microbiol 2005, 54(11):1043-1047.
23. Gonzalez I, Grant KA, Richardson PT, Park SF, Collins MD: Specific identification of the enteropathogens Campylobacter jejuni and Campylobacter coli by using a PCR test based on the ceuE gene encoding a putative virulence determinant. J Clin Microbiol 1997, 35(3):759-763.

24. Denis M, Soumet C, Rivoal K, Ermel G, Blivet D, Salvat G, Colin P: Development of a m-PCR assay for simultaneous identification of Campylobacter jejuni and Campylobacter coli. Lett Appl Microbiol 1999, 29(6):406-410.

25. Abu-Halaweh M, Bates J, Patel BK: Rapid detection and differentiation of pathogenic Campylobacter jejuni and Campylobacter coli by real-time PCR. Res Microbiol 2005, 156(1):107-114.

26. Yang C, Jiang Y, Huang K, Zhu C, Yin Y: Application of real-time PCR for quantitative detection of Campylobacter jejuni in poultry, milk and environmental water. FEMS Immunol Med Microbiol 2003, 38(3):265-271.

27. Rothrock MJ Jr, Cook KL, Bolster CH: Comparative quantification of Campylobacter jejuni from environmental samples using traditional and molecular biological techniques. Can J Microbiol 2009, 55(6):633-641.

28. Hong J, Jung WK, Kim JM, Kim SH, Koo HC, Ser J, Park YH: Quantification and differentiation of Campylobacter jejuni and Campylobacter coli in raw chicken meats using a real-time PCR method. J Food Prot 2007 70(9):2015-2022

29. Josefsen MH, Lofstrom C, Hansen TB, Christensen LS, Olsen JE, Hoorfar J: Rapid quantification of viable Campylobacter bacteria on chicken carcasses, using real-time PCR and propidium monoazide treatment, as a tool for quantitative risk assessment. Appl Environ Microbiol 2010, 76(15):5097-5104.

30. Schnider A, Overesch G, Korczak BM, Kuhnert P: Comparison of real-time PCR assays for detection, quantification, and differentiation of Campylobacter jejuni and Campylobacter coli in broiler neck skin samples. J Food Prot 2010, 73(6):1057-1063.

31. Inglis GD, Kalischuk LD: Direct quantification of Campylobacter jejuni and Campylobacter lanienae in feces of cattle by real-time quantitative PCR. Appl Environ Microbiol 2004, 70(4):2296-2306.

32. Rudi K, Hoidal HK, Katla T, Johansen BK, Nordal J, Jakobsen KS: Direct realtime PCR quantification of Campylobacter jejuni in chicken fecal and ceca samples by Integrated cell concentration and DNA purification. Appl Environ Microbiol 2004, 70(2):790-797.

33. Lagier MJ, Joseph LA, Passaretti TV, Musser KA, Cirino NM: A real-time multiplexed PCR assay for rapid detection and differentiation of Campylobacter jejuni and Campylobacter coli. Mol Cell Probes 2004 18(4):275-282.

34. Leblanc Maridor M, Denis M, Lalande F, Beaurepaire B, Cariolet R, Fravalo P, Seegers H, Belloc C: Quantification of Campylobacter spp. in pig faeces by direct real-time PCR with an internal control of extraction and amplification. J Microbiol Methods

35. Lund M, Nordentoft S, Pedersen K, Madsen M: Detection of Campylobacter spp. in chicken fecal samples by real-time PCR. J Clin Microbiol 2004, 42(11):5125-5132.

36. Koonjul PK, Brandt WF, Farrant JM, Lindsey GG: Inclusion of polyvinylpyrrolidone in the polymerase chain reaction reverses the inhibitory effects of polyphenolic contamination of RNA. Nucl Acids Res 1999, 27(3):915-916.

37. Monteiro L, Bonnemaison D, Vekris A, Petry KG, Bonnet J, Vidal R, Cabrita J, Megraud F: Complex polysaccharides as PCR inhibitors in feces: Helicobacter pylori model. J Clin Microbiol 1997, 35(4):995-998.

38. Skanseng B, Kaldhusdal M, Rudi K: Comparison of chicken gut colonisation by the pathogens Campylobacter jejuni and Clostridium perfringens by real-time quantitative PCR. Mol Cell Probes 2006, 20(5):269-279.

39. Inglis GD, Kalischuk LD: Use of PCR for direct detection of Campylobacter species in bovine feces. Appl Environ Microbiol 2003, 69(6):3435-3447.

40. Rapp D: DNA extraction from bovine faeces: current status and future trends. J Appl Microbiol 2009, 108(5):1485-1493.

41. Schunck B, Kraft W, Truyen U: A simple touch-down polymerase chain reaction for the detection of canine parvovirus and feline panleukopenia virus in feces. J Virol Methods 1995, 55(3):427-433.

42. Hoorfar J, Cook N, Malorny B, Wagner M, De Medici D, Abdulmawjood A, Fach P: Making internal amplification control mandatory for diagnostic PCR. J Clin Microbiol 2003, 41(12):5835. 
43. Burkardt HJ: Standardization and quality control of PCR analyses. Clin Chem Lab Med 2000, 38(2):87-91.

44. Kitchin PA, Bootman JS: Quality Control of the Polymerase Chain Reaction. Rev Med Virol 1993, 3(2):107-114.

45. Matsuda M, Tsukada M, Fukuyama M, Kato Y, Ishida Y, Honda M, Kaneuchi C: Detection of genomic variability among isolates of Campylobacter jejuni from chickens by crossed-field gel electrophoresis. Cytobios 1995, 82(329):73-79.

46. Wassenaar TM, Newell DG: Genotyping of Campylobacter spp. Appl Environ Microbiol 2000, 66(1):1-9.

47. On SL: In vitro genotypic variation of Campylobacter coli documented by pulsed-field gel electrophoretic DNA profiling: implications for epidemiological studies. FEMS Microbiol Lett 1998, 165(2):341-346.

48. Sails AD, Fox AJ, Bolton FJ, Wareing DR, Greenway DL: A real-time PCR assay for the detection of Campylobacter jejuni in foods after enrichment culture. Appl Environ Microbiol 2003, 69(3):1383-1390.

49. Madden RH, Moran L, Scates P: Optimising recovery of Campylobacter spp. from the lower porcine gastrointestinal tract. J Microbiol Methods 2000, 42(2):115-119.

50. Beumer RR, de Vries J, Rombouts FM: Campylobacter jejuni non-culturable coccoid cells. Int J Food Microbiol 1992, 15(1-2):153-163.

51. Rollins DM, Colwell RR: Viable but nonculturable stage of Campylobacter jejuni and its role in survival in the natural aquatic environment. Appl Environ Microbiol 1986, 52(3):531-538.

52. Colles FM, Jones K, Harding RM, Maiden MC: Genetic diversity of Campylobacter jejuni isolates from farm animals and the farm environment. Appl Environ Microbiol 2003, 69(12):7409-7413.

53. Manchester KL: Value of A260/A280 ratios for measurement of purity of nucleic acids. Biotech 1995, 19(2):208-210.

54. Parkhill J, Wren BW, Mungall K, Ketley JM, Churcher C, Basham D, Chillingworth T, Davies RM, Feltwell T, Holroyd S, Jagels K, Karlyshev AV, Moule S, Pallen MJ, Penn CW, Quail MA, Rajandream MA, Rutherford KM, van Vliet AH, Whitehead S, Barrell BG: The genome sequence of the foodborne pathogen Campylobacter jejuni reveals hypervariable sequences. Nature 2000, 403(6770):665-668.

55. Lefébure T, Bitar PD, Suzuki H, Stanhope MJ: Evolutionary dynamics of complete Campylobacter pan-genomes and the bacterial species concept. Genome Biol Evol 2010, 2:646-655.

56. Fouts DE, Mongodin EF, Mandrell RE, Miller WG, Rasko DA, Ravel J, Brinkac LM, DeBoy RT, Parker CT, Daugherty SC, Dodson RJ, Durkin AS, Madupu R, Sullivan SA, Shetty JU, Ayodeji MA, Shvartsbeyn A, Schatz MC, Badger JH, Fraser CM, Nelson KE: Major structural differences and novel potential virulence mechanisms from the genomes of multiple Campylobacter species. PLoS Biol 2005, 3(1):e15.

57. Leblanc Maridor M, Denis M, Lalande F, Beaurepaire B, Cariolet R, Fravalo P, Federighi M, Seegers H, Belloc C: Experimental infection of specific pathogen-free pigs with Campylobacter: excretion in faeces and transmission to non-inoculated pigs. Vet Microbiol 2008, 131(3-4):309-317.

58. Englen MD, Ladely SR, Fedorka-Cray PJ: Isolation of Campylobacter and identification by PCR. Methods Mol Biol 2003, 216:109-121.

59. Kutyavin IV, Lukhtanov EA, Gamper HB, Meyer RB: Oligonucleotides with conjugated dihydropyrroloindole tripeptides: base composition and backbone effects on hybridization. Nucleic Acids Res 1997, 25(18):3718-3723.

60. Kuzio S, Hanguehard A, Morelle M, Ronsin C: Rapid screening for HLA-B27 by a TaqMan-PCR assay using sequence-specific primers and a minor groove binder probe, a novel type of TaqMan ${ }^{T M}$ probe. J Immunol Methods 2004, 287(1-2): 179-186

61. Yao Y, Nellåker C, Karlsson H: Evaluation of minor groove binding probe and Taqman probe PCR assays: Influence of mismatches and template complexity on quantification. Mol Cell Probes 2006, 20(5):311-316.

62. Josefsen MH, Lofstrom C, Sommer HM, Hoorfar J: Diagnostic PCR: comparative sensitivity of four probe chemistries. Mol Cell Probes 2009, 23(3-4):201-203.

63. Stelzl E, Muller Z, Marth E, Kessler HH: Rapid quantification of Hepatitis B virus DNA by automated sample preparation and real-time PCR. J Clin Microbiol 2004, 42(6):2445-2449.

64. Fleiss J: Statistical Methods for Rates and Proportions.Edited by: John Wiley \& Sons Inc Edn. New York: John Wiley; , 2 1981:38-46. doi:10.1186/1471-2180-11-113

Cite this article as: Leblanc-Maridor et al:: Rapid identification and quantification of Campylobacter coli and Campylobacter jejuni by realtime PCR in pure cultures and in complex samples. BMC Microbiology 2011 11:113.

\section{Submit your next manuscript to BioMed Central and take full advantage of:}

- Convenient online submission

- Thorough peer review

- No space constraints or color figure charges

- Immediate publication on acceptance

- Inclusion in PubMed, CAS, Scopus and Google Scholar

- Research which is freely available for redistribution 